\title{
Macro and Micro Mineral Contents in Plasma of Different Age Group Dogs
}

\author{
Sarita $\mathrm{D}^{1 *}$, Sharma $\mathrm{MC}^{1}$ and Yatoo $\mathrm{MI}^{2}$ \\ ${ }^{1}$ Division of Medicine, College of Veterinary Science \& A.H, India \\ 2Indian Veterinary Research Institute, Izatnagar, India
}

*Corresponding author: Sarita Devi, Assistant Professor, TVCC,

\section{Research Article}

Volume 2 Issue 4

Received Date: May 16, 2017

Published Date: August 28, 2017

Sardarkrushinagar, College of Veterinary Science \& AH, SDAU, Sardarkrushinagar, Gujarat, India, E-mail: drsarita17@yahoo.co.in

\section{Abstract}

Minerals play very important role in physiology and metabolism of all living organisms. Plasma macro and micro minerals profile of 226 dogs reported to Referral Veterinary Polyclinic (RVP), IVRI, Izatnagar, belonging to different age and being provided with vegetarian homemade diet by their owners was assessed for estimation of macro (Ca, $\mathrm{P}$, $\mathrm{Mg}, \mathrm{Na}, \mathrm{K}$ ) and microminerals ( $\mathrm{Cu}, \mathrm{Fe}, \mathrm{Zn}, \mathrm{Se}$ and $\mathrm{Co}$ ), and their status analysis. Selected dogs were further subdivided into six (0-1 yr, 1-2 yr, 2-3 yr, 3-4 yr, 4-5 yr and >5 yr) different age groups. Present study revealed deficiency of plasma macro (Ca, P and $\mathrm{Mg}$ ) and micro minerals $(\mathrm{Cu}, \mathrm{Fe}, \mathrm{Zn}, \mathrm{Se})$ in the surveyed dogs.

Keywords: Macro minerals; Micro minerals; Dogs; Age; Plasma

\section{Introduction}

The importance of minerals in regulating biological systems, growth, production and reproduction is well documented [1-3]. Calcium (Ca) and phosphorus (P) are the major macro minerals involved in the formation of bone and cartilage in the body. Other important macro minerals include magnesium $(\mathrm{Mg})$, potassium $(\mathrm{K})$, sodium (Na) and chloride ( $\mathrm{Cl}$ ) which are needed for nerve impulse transmission, muscle contraction, and cell signaling. Trace element status influences growth and reproduction (Zinc (Zn), Selenium (Se)), immune functions (Zn, Se, Iron (Fe)), cognitive functions (Zn, Se), bone density (Copper ( $\mathrm{Cu}), \mathrm{Zn}$ ), and oxidative stress $(\mathrm{Zn}, \mathrm{Se}, \mathrm{Cu}, \mathrm{Fe})[4,5]$. Deficiencies in pets are uncommon in western developed countries as a result of widespread feeding of complete and balanced pet foods that meet the nutrient profiles specified by the expert's cientific panel. But, the scenario in India is quite different, where homemade diets constitute the mainstay of feeding with majority pet owners feeding the dogs according to their own convenience and perceptions [6]. However, more precise information is still required about nearly every essential nutrient for companion animals, bioavailability of nutrients and their interactions. Keeping in view the above facts, present clinical research work was undertaken to estimate plasma macro ( $\mathrm{Ca}, \mathrm{P}, \mathrm{Mg}, \mathrm{Na}, \mathrm{K}$ ) and micro minerals $(\mathrm{Cu}, \mathrm{Fe}, \mathrm{Zn}, \mathrm{Se}, \mathrm{Co})$, and status analysis in dogs.

\section{Materials and Methods}

Plasma profile of macro and micro minerals of 226 dogs reported to Referral Veterinary Polyclinic (RVP), IVRI, Izatnagar, belonging to different age group and being provided with vegetarian homemade diet by their owners was assessed for estimation of macro ( $\mathrm{Ca}, \mathrm{P}, \mathrm{Mg}$, $\mathrm{Na}$ and $\mathrm{K}$ ) and micro minerals ( $\mathrm{Cu}, \mathrm{Fe}, \mathrm{Zn}$, Se and $\mathrm{Co}$ ), and status analysis. Selected dogs were further subdivided into six (0-1 yr, 1-2 yr, 2-3 yr, 3-4 yr, 4-5 yr and $>5 \mathrm{yr}$ ) different age groups. Plasma samples were digested for mineral estimation (Table 1) [7]. Ca, P, Na and $\mathrm{K}$ was estimated spectrophotometrically using commercial kits obtained from Span diagnostic, Surat as per manufacturer instructions. $\mathrm{Cu}, \mathrm{Fe}, \mathrm{Zn}, \mathrm{Co}$, Se and $\mathrm{Mg}$ were estimated using atomic absorption spectrophotometer (ECIL AAS 4141). Data collected was analyzed as per the method described by Snedecor and Cochran [8]. 


\section{Open Access Journal of Veterinary Science \& Research}

\begin{tabular}{|c|c|c|c|c|c|c|c|}
\hline \multirow[t]{2}{*}{ Parameter } & \multicolumn{6}{|c|}{ Age group } & \multirow{2}{*}{$\begin{array}{c}\text { Reference } \\
\text { value }\end{array}$} \\
\hline & $0-1 \mathrm{yr}$ & $1-2 \mathrm{yr}$ & $2-3 \mathrm{yr}$ & $3-4 \mathrm{yr}$ & $4-5 \mathrm{yr}$ & $>5 \mathrm{yr}$ & \\
\hline $\mathrm{Ca}(\mathrm{mg} / \mathrm{dl})$ & $8.74 \pm 0.41$ & $8.44 \pm 0.34$ & $8.07 \pm 0.44$ & $7.80 \pm 0.62$ & $7.64 \pm 0.29$ & $7.46 \pm 0.22$ & $8.7-11.8$ \\
\hline $\mathrm{P}(\mathrm{mg} / \mathrm{dl})$ & $3.52 \pm 0.29^{b}$ & $3.34 \pm 0.21^{\mathrm{ab}}$ & $3.47 \pm 0.32^{\mathrm{ab}}$ & $3.38 \pm 0.22^{\mathrm{ab}}$ & $3.45 \pm 0.24^{b}$ & $2.35 \pm 0.22^{\mathrm{a}}$ & $2.9-6.2$ \\
\hline $\mathrm{Mg}(\mathrm{mg} / \mathrm{dl})$ & $1.45 \pm 0.08$ & $1.37 \pm 0.06$ & $1.46 \pm 0.13$ & $1.32 \pm 0.08$ & $1.47 \pm 0.10$ & $1.24 \pm 0.09$ & $1.7-2.7$ \\
\hline $\mathrm{Na}(\mathrm{mEq} / \mathrm{L})$ & $138.00 \pm 2.45$ & $141.73 \pm 3.78$ & $142.22 \pm 1.74$ & $143.32 \pm 1.49$ & $144.09 \pm 2.16$ & $144.66 \pm 1.22$ & $140-154$ \\
\hline $\mathrm{K}(\mathrm{mEq} / \mathrm{L})$ & $4.07 \pm 0.12$ & $4.05 \pm 0.29$ & $4.20 \pm 0.20$ & $4.26 \pm 0.13$ & $4.48 \pm 0.12$ & $4.49 \pm 0.13$ & $3.8-5.6$ \\
\hline $\mathrm{Cu}(\mu \mathrm{g} / \mathrm{dl})$ & $0.48 \pm 0.03$ & $0.54 \pm 0.02$ & $0.55 \pm 0.03$ & $0.59 \pm 0.02$ & $0.57 \pm 0.02$ & $0.53 \pm 0.05$ & \\
\hline $\mathrm{Fe}(\mu \mathrm{g} / \mathrm{dl})$ & $0.82 \pm 0.05$ & $0.84 \pm .09$ & $0.99 \pm 0.08$ & $0.89 \pm 0.04$ & $1.06 \pm 0.05$ & $0.94 \pm 0.05$ & \\
\hline $\mathrm{Zn}(\mu \mathrm{g} / \mathrm{dl})$ & $0.47 \pm 0.03$ & $0.52 \pm 0.02$ & $0.56 \pm 0.02$ & $0.52 \pm 0.02$ & $0.55 \pm 0.06$ & $0.50 \pm 0.04$ & \\
\hline Se $(\mu \mathrm{g} / \mathrm{dl})$ & $0.11 \pm 0.008^{\mathrm{ab}}$ & $0.13 \pm 0.004^{\mathrm{bc}}$ & $0.14 \pm 0.005^{\mathrm{bc}}$ & $0.15 \pm 0.006^{c}$ & $0.14 \pm 0.003^{\mathrm{bc}}$ & $0.12 \pm 0.007^{\mathrm{a}}$ & \\
\hline Co $(\mu \mathrm{g} / \mathrm{dl})$ & $0.025 \pm 0.0008$ & $0.024 \pm 0.0009$ & $0.026 \pm 0.001$ & $0.026 \pm 0.0008$ & $0.023 \pm 0.001$ & $0.022 \pm 0.001$ & \\
\hline
\end{tabular}

Table 1: Plasma macro and micro minerals profile (mean $\pm \mathrm{SE}$ ) of Dogs of different age group.

Values with different superscript differ significantly $(\mathrm{P}<0.05)$ between the group.

Values with identical superscript do not differ significantly $(\mathrm{P}<0.05)$ between the group.

\section{Results and Discussion}

The mean concentration of $\mathrm{Ca}$ and $\mathrm{Mg}$ was nonsignificantly different and towards lower range in dogs of different age groups. Tilkian et al. [9] opined that Ca is a highly regulated blood mineral and any marked change in serum concentration of this ion indicates possible metabolic and endocrine dysfunction. Concentration of Ca towards higher range $(8.74 \pm 0.41)$ was recorded from $0-1 \mathrm{yr}$ and towards lower range $(7.46 \pm 0.22)$ from $>5$ yr age group dogs in the present study. Our findings were in agreement with Hedhammar [10] who stated that because of rapid bone growth, concentrations of Ca are often elevated slightly in young growing dogs and with Kaspar and Norris [11] who stated that because of retardation of bone growth, concentrations of $\mathrm{Ca}$ are often lowered in geriatric dogs.

Concentration of $\mathrm{Mg}$ is low which might be due to low fiber, less bone meal and no supplementation of nonveg in the home made food of dog. The principal role of $\mathrm{Mg}$ ionis Ca channel blocking agent and to regulate heart and skeletal muscle function. Mg deficiency is also pro-inflammatory and is associated with increases in oxidative stress in vivo and cardiac susceptibility toischemia/reperfusion (I/R) injury [12].

Concentration of $\mathrm{P}$ in growing age groups was found to be in lower range but significantly $(\mathrm{p}<0.05)$ higher as compared to older dogs which is in agreement with the findings of Kaspar and Norris [11] who opined that concentration of $\mathrm{P}$ is known to be high in young dogs due to normal bone growth and because of retardation of bone growth, concentrations of $\mathrm{P}$ are often lowered in geriatric dogs. Similarly, other researchers [13-15] have also reported higher total $\mathrm{Ca}$ and $\mathrm{P}$ levels in dogs $>6$ months of age. In this age, the action of growth hormone
(GH) and osteosynthesis are at their highest level with the formation of ossification nucleus, longitudinal growth and bone maturation reflecting high physiological levels of these serum biochemical markers [16].

Plasma $\mathrm{Na}, \mathrm{K}$, and Co concentration were nonsignificantly ( $p>0.05)$ different in dogs of different age groups and were in normal range. Normal plasma $\mathrm{Na}$ and $\mathrm{K}$ concentrations are maintained by balanced intake and excretion, intracellular and extracellular osmotic pressure, and $\mathrm{pH}[17,18]$ stated that Co deficiency per se has never been clearly demonstrated in monogastric species. In non-ruminants, Co and Fe appear to share a common intestinal transport system and Co absorption is greatly increased in Fe deficiency [19].

The mean concentration of $\mathrm{Cu}, \mathrm{Fe}$ and $\mathrm{Zn}$ was not significantly $(p>0.05)$ different and towards lower range in dogs of different age groups. Most meat ingredients, especially organ meats are rich in $\mathrm{Cu}$ and $\mathrm{Zn}$. Deficiency of $\mathrm{Cu}$ is marked by microcytic, hypochromic anemia and often, by a reddish tinge to the hair in a white-haired animal. Dogs may also experience a higher demand for $\mathrm{Zn}$ under circumstances of stress, during growth periods, levels of high activity, gestation, lactation or illness [20]. In adult pets, signs of $\mathrm{Zn}$ deficiency are confined mainly to the skin, but these may be accompanied by impaired growth and other abnormalities in young animals.

Concentration of $\mathrm{Fe}$ was lowest $(0.82 \pm 0.05)$ in dogs from 0-1 yr age group. The lower serum Fe observed in animals under 6 months can be explained by their small food intake and the animal's high demand in response to rapid growth [21]. Furthermore, studies have shown the availability of Fe to be relatively high from liver, 


\section{Open Access Journal of Veterinary Science \& Research}

muscle and animal by-products [22]. Young puppies are especially vulnerable because of the low Fe content of milk.

In the present study, the mean concentration of plasma Se was significantly $(\mathrm{p}<0.05)$ lower in $>5 \mathrm{yr}$ $(0.11 \pm 0.008)$ and $0-1 \mathrm{yr}(0.12 \pm 0.007)$ age group of dogs. In animals, most of the studies focused on Se status in cattle and pigs. Limited number of deficiency studies reported in dogs. The lower concentration might be due to the provision of only vegetarian diet to the dogs as fish, meat and poultry products are typical sources of this nutrient.

On the basis of the findings of the present study it can be concluded that analysis of blood should be done periodically in dogs for monitoring mineral status for preventing diseases.

\section{Acknowledgment}

Authors are thankful to Director, IVRI for providing valuable assets for completion of the research work.

\section{References}

1. Kumar P, Sharma MC, Joshi C (2007) Effect on biochemical profile concurrent with micro-mineral deficiencies in buffaloes (Bubalusbubalis) of Eastern Uttar Pradesh. Indian Journal of Animal Sciences 77: 86-91.

2. Sharma MC, Joshi C, Kumar M (2005) Micro minerals- their deficiency disorders and treatment: a review. Indian Journal of Animal Sciences 75: 246257

3. Underwood EJ, Suttle NF (1999) The Mineral Nutrition of Livestock. $3^{\text {rd }}$ (Edn.), CAB International Publishing Company.

4. Roussel AM (2000) New aspects on trace element metabolism disturbances in man and pet animals. Revue de Medecine Veterinaire 151: 637-642.

5. Kumar P (2006) Status of mineral in soil-fodderanimal in relation to immunity in bovines of Bihar state and \& evaluation of efficacy of area specific mineral supplementation. PhD Thesis, Submitted to Deemed University, IVRI, Izatnagar.

6. Pattanaik AK, Sharma K (2006) Nutritional adequacy of homemade diets for pet dogs. In: Proceedings of Nutritional Congress of Canine Practice. 3rd Annual Convention of Indian Society for Advancement of canine Practice, Bhubaneswar pp. 185-193.
7. Yatoo MI, Archana S, Pankaj K, Mudasir BG, Umesh D, et al. (2013) Evaluation of serum mineral status and hormone profile in goats and some of their inter-relations. Veterinary World 6(6): 318-320.

8. Snedecor GW, Cochran WG (1994) Statistical methods. Iowa State University Press.

9. Tilkian SM, Conver MB, Tilkian SJ (1983) Clinical Implications of Laboratory Tests. $3^{\text {rd }}$ (Edn.), CV Mosby.

10. Hedhammer A (1996) Nutrition related orthopedic diseases. In: Manual of Companion Animal Nutrition and Feeding. Iowa State Uni Press, Ames.

11. Kaspar LV, Norris WP (1977) Serum chemistry values of normal dogs (beagles): Associations with age, sex, and family line. Laboratory Animal Sciences 27(6): 980-985.

12. Kramer JH, Mak IT, Phillips TM, Weglicki WB (2003) Dietary magnesium intake influences circulating pro-inflammatory neuropeptide levels and loss of myocardial tolerance to postischemic stress. Experimental Biological Medicine 228(6): 665-673.

13. Wolford ST, Schroer RA, Gohs FX, Gallo PP, Falk HB, et al. (1988) Effect of age on serum chemistry profile, electrophoresis and thyroid hormones in beagle dogs two weeks to one year of age. Veterinary Clinical Pathology 17(2): 35-42.

14. Ikeuchi J, Yoshizaki T, Hirata M (1991) Plasma biochemistry values of young beagle dogs. Journal Toxicological Science 16(2): 49-59.

15. Swanson KS, Kuzmuk KN, Schook LB, Fahey GC (2004) Diet affects nutrient digestibility, hematology, and serum chemistry of senior and weanling dogs. Indian Journal of Animal Sciences 82(6): 1713-1724.

16. Castillo V, Marquez A, Rodriguez M, Lalia J (1997) Parametrosbioquimico-endocrinos de utilidad en la etapadelcrecimientoyd esarrollo del Ovejero Alemán, Doberman Great Danes. Archivos de Medicina Veterinaria 29: 105-111.

17. Brobst D (1986) Review of the pathophysiology of alterations in potassium homeostasis. Journal of American Veterinary Medical Association 188(9): 1019-1025.

18. Mc Dowell LR (1992) Minerals in Animal and Human Nutrition. Academic Press. 


\section{Open Access Journal of Veterinary Science \& Research}

19. Thomson ABR, Valberg LS, Sinclair DC (1971) Competitive nature of the intestinal transport mechanism for cobalt and iron in the rat. The Journal of Clinical Investigation 50(11): 2384-2394.

20. Morris JG, Rogers QR (1995) Copper oxide is ineffective source of copper in queen diets. In: Proceedings of Pet food Forum, pp: 107-108.
21. Smith JE (1989) Iron metabolism and its diseases. In: Clinical biochemistry of domestic animals. $4^{\text {th }}$ (Edn.), Academic press.

22. Conrad HR, Zimmerman DR, Combs GF (1980) Literature Review on Iron in Animal and Poultry Nutrition. West Des Moines, IA: National Feed Ingredients Association. 